\title{
PEMBUATAN KOMPOS TANKOS KELAPA SAWIT \\ DENGAN MEMANFAATKAN STATER ORGANIK MENUJU MASYARAKAT UNGGUL DAN SEJAHTERA
}

\author{
Benediktus Ege, Hendrikus Julung, Andri, Leliavia, Yuniarti Essi Utami \\ ama_tamo@yahoo.com, henjulung@gmail.com, \\ andry_tkr@yahoo.com, Avhialely@gmail.com, Yuniartiessi@gmail.com
}

\begin{abstract}
The agricultural business becomes the economic growth of the community in Kuala Dua Village, Kembayan Sub-district, Sanggau District, West Kalimantan. The rubber and oil palm agriculture became the primadonna of local communities, while other agricultural enterprises such as horticultural agriculture have not been professionally developed, but the results of both sectors haven't been able to raise the economic prosperity of farmers. From the financial side, people don't have a good financial management of their income. On the other hand there are potential areas that can be developed to improve the economy of the peoples. One of them is the utilization of waste palm oil empty bunches to be made organic fertilizer with its composition with the help of organic stater that provides great benefits in the horticultural crops business. Purpose of PkM Activities: 1)Understanding of : environment; Benefits, functions and problems of household hygiene and agricultural waste; negative impacts and positive potential of empty palm oil bunch waste; 2) training on how to: make organic stater from household waste and agricultural waste; compost from oil palm empty bunches; use of compost from oil palm empty bunches on horticultural crops; financial management to support investment in agricultural business. PkM held on Monday, December 11, 2017 in the village of Kuala Dua Kembayan District Sanggau District. and attended by 52 Participants. The methods used are Counseling, Training and Practice directly between Team PkM and Participants

Keywords: Compost, Tankos Palm Oil, Organic Stater
\end{abstract}

Abstrak: Usaha bidang pertanian menjadi urat nadi pertumbuhan ekonomi masyarakat di Desa Kuala Dua, Kecamatan Kembayan, Kabupaten SanggauKalimantan Barat. Pertanian karet dan sawit menjadi primadona masyarakat setempat, sedangkan usaha pertanian lainya seperti pertanian hortikultura belum dikembangkan secara professional, namun hasil dari kedua sektor tersebut belum mampu mengangkat kesejahteraan petani. Dari sisi keuangan, masyarakat belum memiliki pengelolaan yang cermat terhadap pendapatan yang diperoleh. Dilain pihak ada potensi daerah yang dapat dikembangkan untuk meningkatkan taraf kehidupan petani. Salah satunya adalah pemanfaatan limbah tandan kosong kelapa sawit untuk dijadikan pupuk organik (kompos) dengan bantuan stater organik yang memberikan manfaat besar dalam usaha pertanian tanaman hortikultura. Tujuan kegiatan PkM: 1) Memberikan pemahaman tentang: lingkungan; Manfaat, Fungsi dan pentingnya mengelola limbah rumah tangga dan limbah pertanian; dampak negatif dan potensi positif dari limbah tandan kosong kelapa sawit, 2) Memberikan pelatihan tentang cara: membuat stater organik dari limbah rumah tangga dan limbah pertanian; membuat kompos dari tandan kosong kelapa sawit; 
penggunaan kompos dari tandan kosong kelapa sawit pada tanaman hortikultura; mengelola keuangan untuk mendukung investasi dalam bidang usaha pertanian. PkM dilaksanakan pada hari Senin, 11 Desember 2017 di Desa Kuala Dua Kecamatan Kembayan Kabupaten Sanggau. dan dihadiri oleh 52 Peserta. Metode yang digunakan adalah Penyuluhan, Pelatihan dan praktik langsung antara Tim PkM dengan Peserta.

Kata Kunci : Kompos, Tankos Kelapa Sawit, Stater Organik

\section{PENDAHULUAN}

Usaha bidang pertanian masih jadi urat nadi pertumbuhan ekonomi bagi sebagian besar masyarakat di Dusun Jemongko, Desa Kuala Dua, Kecamatan Kembayan, Kabupaten Sanggau, Provinsi Kalimantan Barat. Dusun Jemongko, Desa Kuala Dua, Kecamatan Kembayan, Kabupaten Sanggau terletak 215 Km dari Kabupaten Sintang. Dapat ditempuh dengan perjalanan menggunakan kendaraan bermotor roda dua \pm 5 Jam dari Kota Sintang (www. jarakantarkota.com). Perjalanan menggunakan roda empat hanya dapat dilakukan sampai pada desa kuala dua saja, sedangkan untuk menuju Dusun Jemongko, hanya dapat ditempuh dengan menggunakan kendaraan roda dua. Hal ini dikarenakan jembatan penyebarangan yang melintasi sungai Sekayam yang menghubungkan Desa Kuala Dua dengan Dusun Jemongko, hanya bisa dilalui kendaraan roda dua saja (Jembatan Gantung).

Masyarakat di Dusun Jemongko, Desa Kuala Dua sebagian besar adalah petani sawit dan karet baik yang dimiliki sendiri maupun yang dimiliki oleh perusahaan. Hal ini terlihat dari demografi wilayah Kabupaten Sanggau yang mayoritas perkebunan di dominasi oleh kelapa sawit, salah satunya di Dusun Jemongko, Desa Kuala Dua. Berdasarkan data statistik, dari seluruh wilayah di Kalimantan Barat, Kabupaten Sanggau merupakan penghasil perkebunan sawit terbesar.

Produksi kelapa sawit Kabupaten Sanggau yang mencapai 171.472 ton atau 40,05 persen dari total produksi Kalimantan Barat (Tastuti, 2016). Oleh karena itu tidak mengherankan, pendapatan masyarakat khususnya di Dusun Jemongko juga masih mengandalkan pada kedua sektor tersebut sedangkan hasil lainnya berasal dari pertanian konvensional seperti berladang dan membuka persawahan. Selanjutnya dalam kehidupan sosial kemasyarakatan, penduduk di Dusun Jemongko masih mempertahankan nilainilai luhur budaya. Hukum adat masih

Ege, dkk, Pembuatan Kompos...61. 


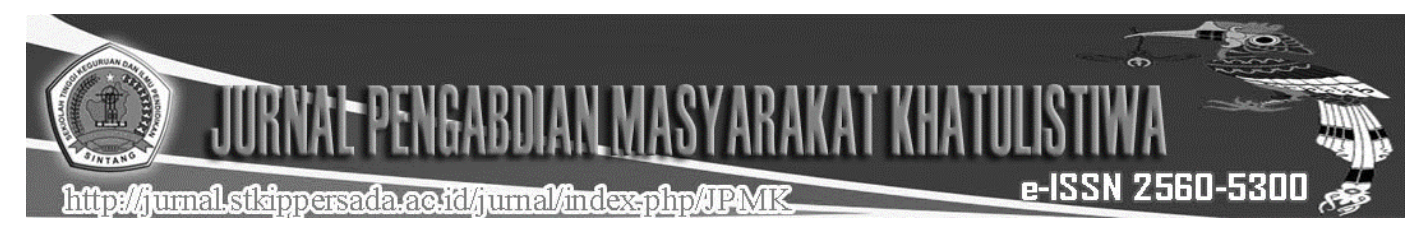

diterapkan dengan baik pada semua aspek kehidupan di masyarakat.

Masyarakat Dusun Jemongko, mayoritas suku Dayak Muara dan sebagian kecil suku pendatang seperti china, melayu dan jawa. Kemudian, dari segi agama, mayoritas masyarakat Dusun Jemongko beragama Katolik di ikuti Protestan, dan sebagian kecil Islam. Jumlah KK di Dusun Jemongko sebanyak 179 KK. Sementara itu dari aspek kesehatan masyarakat Dusun Jemongko cukup terlayani dengan baik, karena sudah tersedia fasilitas layanan kesehatan di Desa Kuala yang jaraknya cukup terjangkau dari Dusun Jemongko. Adapun untuk mutu layanan, yang masih dirasakan masih kurang oleh masyarakat adalah keberadaan jembatan gantung yang belum secara maksimal dapat melayani akses kebutuhan masyarakat seperti mengangkut hasil bumi dalam jumlah yang banyak karena hanya bisa dilalui oleh kendaraan roda dua saja, selain itu kebutuhan air bersih karena masih mengandalkan air sungai dan air hujan.

Permasalahan lain yang di hadapi masyarakat adalah pendapatan per kapita keluarga petani yang masih di rentang menengah ke bawah (Rp.1.000.000/bulan). Hal ini disebabkan masyarakat petani lebih banyak yang bekerja sebagai buruh

sawit dan karet diperusahaan dibandingkan kepemilikan sendiri. Sementara usaha lainnya hanya berladang secara konvensional. Belum ada usaha perkebunan lainnya yang dikembangkan untuk menunjang perekonomian keluarga. Ketiadaan pengetahuan dan keterampilan membuat masyarakat tidak merasa yakin untuk mengembangkan jenis-jenis tanaman hortikultura khususnya sayur-sayuran yang memiliki nilai ekonomis.

Melalui kegiatan Pengabdian kepada Masyarakat (PkM) ini masyarakat Dusun Jemonko diharapkan memiliki pengetahuan dan keterampilan tambahan dalam membudidayakan tanaman hortikultura bernilai ekonomis dengan memanfaatkan stater organik dalam pembuatan kompos dari tandan kosong (tankos) kelapa sawit. Penggunaan stater organik mempercepat proses dekomposerisasi dalam pengomposan.

Bahan yang digunakan untuk membuat stater organik ini dapat berasal dari limbah rumah tangga (seperti: air cucian beras dan sayuran bekas yang tidak dimanfaatkan) dan limbah pertanian (seperti: bonggol pisang dan sekam padi). Bahan-bahan tersebut sangat mudah dijumpai dan didapatkan di sekitar masyarakat. Sementara itu tandan kosong kelapa sawit sebagai bahan dasar kompos juga tidak kalah Ege, dkk, Pembuatan Kompos...62. 
mudah diperoleh, karena masyarakat Dusun Jemongko yang sebagian besar bekerja sebagai petani dan buruh perkebunan sawit. Selama ini bahanbahan untuk pembuatan stater dan kompos tersebut hanya menjadi limbah yang tidak bermanfaat dan menimbulkan efek kurang baik bagi lingkungan.

Tandan Kosong Kelapa Sawit (TKKS) merupakan limbah perkebunan sawit. Pabrik kelapa sawit (PKS) menghasilkan limbah yang cukup besar, baik limbah padat maupun cair. Pabrik dengan kapasitas kecil dapat menghasilkan limbah sekitar 10-15 ton/hari. Kandungan hara kompos limbah kebun pabrik kelapa sawit pada umumnya N 1,17\%; Fosfat (P) 2,5\%; Kalsium (Ca) 1,35\%; Kalium (K) 1,62\%; dan C-organik 28,53\% (Suwahyono, 2014: 15). Jika kompos TKKS ini digunakan dan dikelola dengan baik akan mencukupi bahan organik dalam tanah sehingga kebutuhan tanaman akan nutrisi atau unsur hara saat pertumbuhan dapat tercukupi.

Limbah padat kelapa sawit berupa tandan kosong kelapa sawit (TKSS) sangat berpotensi untuk digunakan sebagai bahan dasar kompos. Namun demikian, dewasa ini pemanfaatannya belum digunakan secara optimal karena selama ini hanya digunakan sebagai mulsa dan dibuang diareal pertanaman sawit. Limbah tersebut dapat digunakan sebagai bahan baku dalam pembuatan kompos, tetapi proses pengomposannya memerlukan waktu yang sangat lama yaitu 12-18 bulan, sehingga proses yang lama disertai kurangnya pengetahuan dan keterampilan, membuat petani lebih memilih menggunakan pupuk kimia. Oleh karena itu, untuk pengomposan limbah kelapa sawit memerlukan metode tersendiri, misalnya menambahkan bioaktivator yang mengandung jamur dari genus Trichoderma yang digunakan sebagai stater dalam proses dekomposerisasi pembuatan kompos. Melalui teknik tersebut proses pengomposan dapat dipercepat sehingga hanya memerlukan waktu yang singkat. Tentunya pembuatan pupuk kompos atau organik dengan waktu yang relatif singkat tersebut, perlu dilatihkan kepada masyarakat petani.

Pupuk organik (kompos) merupakan hasil akhir dan atau hasil antara dari perubahan atau peruraian bagian dan sisa-sisa tanaman dan hewan, misalnya bungkil, guano, tepung tulang, limbah ternak dan lain sebagainya (Murbandono, 2002). Pupuk organik merupakan pupuk yang terbuat dari bahan-bahan organik yang didegradasikan secara organik dengan bantuan mikroorganisme pengurai.

Ege, dkk, Pembuatan Kompos...63. 
Sumber bahan baku organik ini dapat diperoleh dari bermacam-macam sumber, seperti: kotoran ternak, sampah rumah tangga non sintetis berupa sayursayuran dan buah-buahan, serta cucian beras, limbah-limbah makanan/minuman, dan limbah pertanian. Pembuatan pupuk organik ini biasanya ditambahkan stater baik yang sintetik maupun yang alami (organik) berupa larutan yang mengandung mikroorganisme yang akan membantu mempercepat proses pendegradasian (Prihandarini, 2004). Mikroorganisme tersebut dapat memanfaatkan larutan yang terdapat mikroorganisme lokal (MOL) yang dapat dibuat sendiri dari sisa sampah rumah tangga dan tanamantanaman local serta sampah hasil pertanian.

Penggunaan pupuk organik dengan memanfaatkan Tankos Kelapa Sawit dengan bantuan Stater Organik memiliki keunggulan karena mampu meningkatkan kesuburan tanah, membantu penyerapan unsur hara dalam tanah dan tidak memberikan dampak negatif terhadap lingkungan. Selain itu, untuk membuat pupuk organik, petani tidak perlu mengeluarkan biaya yang besar seperti halnya jika petani harus membeli pupuk kimia untuk keperluan bercocok tanam. Dengan demikian biaya produksi dan perawatan tanaman dapat Volume 1 Nomor 2 Nopember 2018 ditekan seminimal mungkin. Hal ini berbeda dengan penggunaan pupuk kimia. Penggunaan pupuk kimia secara kontinu dan dalam jumlah yang besar akan berdampak negatif baik bagi lingkungan maupun bagi tanaman. Penggunaan pupuk anorganik secara terus-menerus tanpa tambahan pupuk organik dapat menguras bahan organik tanah dan menyebabkan degradasi kesuburan hayati tanah (Ayu dkk, 2015).

Melalui variasi usaha pertanian dengan memanfaatkan metode ilmiah yang murah dan ramah lingkungan diharapkan masyarakat petani di Dusun Jemongko dapat menjadi petani yang unggul dan sejahtera. Unggul karena masyarakat memiliki pengetahuan, kemampuan dan keterampilan dalam memanfaatkan teknik modern dalam membuat pupuk organik yang murah dan ramah lingkungan namun efektif dalam mengembangkan usahan pertanian hortikultura. Sejahtera, karena masyarakat dalam kegiatan Pengabdian kepada Masyarakat ini selain diberikan pelatihan dalam membuat pupuk organik dengan metode ilmiah sederhana, juga diberikan penyuluhan tentang pengelolaan keuangan. Tujuannya agar masyarakat mampu menjamin keberlangsungan usaha pertaniannya untuk jangka waktu yang panjang. Sehingga cita-cita menuju masyarakat Ege, dkk, Pembuatan Kompos...64. 
yang unggul dan sejahtera dapat tercapai.

Tujuan kegiatan PkM ini yaitu: 1) Memberikan pemahaman tentang lingkungan, 2) Memberikan pemahaman tentang Manfaat, Fungsi dan pentingnya mengelola limbah rumah tangga dan limbah pertanian, 3) Memberikan pemahaman tentang dampak negatif dan potensi positif dari limbah tandan kosong kelapa sawit, 4) Memberikan pelatihan tentang cara membuat stater organik dari limbah rumah tangga dan limbah pertanian, 5) Memberikan pelatihan tentang cara membuat kompos dari tandan kosong kelapa sawit, 6) Memberikan pelatihan tentang cara penggunaan kompos dari tandan kosong kelapa sawit pada beberapa tanaman hortikultura, 7) Memberikan pelatihan tentang cara mengelola keuangan untuk mendukung investasi dalam bidang usaha pertanian

Rencana pemecahan masalah dalam kegiatan PkM ini dalam bentuk Penyuluhan dan Pelatihan ini yaitu dengan langkah-langkah: 1) Masyarakat diberikan pemahaman tentang pentingnya menjaga lingkungan, 2) Masyarakat diberikan pemahaman tentang Manfaat, Fungsi dan pentingnya mengelola limbah rumah tangga dan limbah pertanian, 3) Masyarakat diberikan pemahaman tentang dampak negatif dan potensi positif dari limbah tandan kosong kelapa sawit, 4) Masyarakat diberikan Pelatihan tentang cara membuat stater organik dari limbah rumah tangga dan limbah pertanian, 5) Masyarakat diberikan Pelatihan tentang cara membuat kompos dari tandan kosong kelapa sawit, 6) Masyarakat diberikan Pelatihan tentang cara penggunaan kompos dari tandan kosong kelapa sawit pada beberapa tanaman hortikultura, 7) Masyarakat diberikan pendidikan dan pelatihan tentang cara mengelola keuangan untuk mendukung investasi dalam bidang usaha pertanian pada lembaga-lembaga keuangan.

\section{METODE PELAKSANAAN}

Metode pelaksanaan dalam kegiatan PkM ini yaitu dalam bentuk Penyuluhan dan Pelatihan. Adapun tahap atau langkah-langkah kegiatan yaitu sebagai berikut: 1) Peserta diberikan materi tentang Lingkungan 2) Peserta diberikan materi Manfaat, Fungsi dan pentingnya mengelola limbah rumah tangga dan limbah pertanian, 3) Peserta diberikan materi tentang dampak negatif dan potensi positif dari limbah tandan kosong kelapa sawit, 4) Peserta diberikan pelatihan tentang cara membuat stater organik dari limbah rumah tangga dan limbah pertanian, 5) Peserta diberikan pelatihan tentang cara

Ege, dkk, Pembuatan Kompos...65. 
membuat kompos dari tandan kosong kelapa sawit, 6) Peserta diberikan pelatihan tentang cara penggunaan kompos dari tandan kosong kelapa sawit pada beberapa tanaman hortikultura, 7) Peserta diberikan pendidikan dan pelatihan tentang cara mengelola keuangan dan melakukan investasi dalam bidang usaha pertanian pada lembaga-lembaga keuangan, 8) Peserta diarahkan untuk membuka tabungan untuk persiapan pendidikan anak bisa di KUD, CU dan Bank.

\section{HASIL DAN PEMBAHASAN}

Kegiatan PkM dalam bentuk Penyuluhan dan Pelatihan yang berjudul "Pembuatan Kompos Tankos Kelapa Sawit Dengan Memanfaatkan Stater Organik Menuju Masyarakat Unggul Dan Sejahtera" sudah dilaksanakan dengan acara tatap muka dan praktek tentang pembuatan stater organik, pembuatan kompos dan pelatihan pengelolaan keuangan keluarga untuk usaha perkebunan masyarakat . Pertemuan tatap muka dilakukan dengan metode ceramah dan demonstrasi, dilanjutkan dengan pelatihan yaitu latihan/praktek membuat stater, membuat pupuk organik dan pengelolaan keuangan dan investasi dibidang perkebunan.
Kegiatan ini dilaksanakan selama satu hari yaitu pada hari Senin, 11 Desember 2017 di Desa Kuala Dua Kecamatan Kembayan Kabupaten Sanggau. Kegiatan dimulai pada pukul 13.00 - 17.00 Wib di Gedung Sekolah SD Negeri 28 Jemongko Desa Kuala Dua dengan susunan acara sebagai berikut:

1. Menyanyikan Lagu "Indonesia Raya"

2. Kata Sambutan Ketua PkM.

3. Kata Sambutan Kepala Desa Sekaligus Membuka secara Resmi Kegiatan PkM

4. Doa

5. Pemateri I tentang "Manfaat, Fungsi dan pentingnya mengelola limbah rumah tangga dan limbah pertanian"

6. Pemateri II Tentang "cara membuat stater organik dari limbah rumah tangga dan limbah pertanian"

7. Pemateri III Pelatihan "cara membuat kompos dari tandan kosong kelapa sawit"

8. Pemateri IV Pelatihan "cara penggunaan kompos dari tandan kosong kelapa sawit pada beberapa tanaman hortikultura"

9. Pemateri V Pelatihan "cara mengelola keuangan dan

Ege, dkk, Pembuatan Kompos...66. 
melakukan investasi dalam bidang usaha pertanian pada lembagalembaga keuangan".

10. Penutup

Pelaksanaan Kegiatan dilakukan oleh 5 Orang Tim Pengabdi sebagai pemateri dan dibantu mahasiswa yang melaksanakan kegiatan PPL\&KKM Terpadu di Desa Kuala Dua, dengan materi yang telah dipaparkan pada susunan acara diatas. Pemateri pertama (I) Benediktus Ege,M.Pd, Pemateri Dua (II) Hendrikus Julung, M.Pd, Pemateri Tiga (III) Leliavia, M.Pd, Pemateri Empat (IV) Yuniarti Essi Utami, M.Pd dan Pemateri Kelima (V) Andri, M.Pd. Keterbatasan waktu pertemuan mengakibatkan tidak semua materi dan pelatihan dapat disampaikan dengan maksimal.

Peserta yang menghadiri kegiatan ini yaitu anggota masyarakat yang berada di Desa Kuala Dua yaitu Kelompok Tani. Total peserta yang hadir dalam kegiatan penyuluhan dan pelatihan ini yaitu sebanyak 52 peserta

Materi pertama yaitu tentang “ Manfaat, Fungsi dan pentingnya mengelola limbah rumah tangga dan limbah pertanian", dengan materi ini masyarakat diberi pendidikan lingkungan hidup. Pendidikan lingkungan hidup adalah suatu proses untuk membangun populasi manusia di dunia yang sadar dan peduli terhadap lingkungan total (keseluruhan) dan segala masalah yang berkaitan dengannya, dan masyarakat yang memiliki pengetahuan, ketrampilan, sikap dan tingkah laku, motivasi serta komitmen untuk bekerja sama, baik secara individu maupun secara kolektif , untuk dapat memecahkan berbagai masalah lingkungan saat ini, dan mencegah timbulnya masalah baru. (UNESCO, Deklarasi Tbilisi, 1977 dalam Wikipedia). Pendidikan lingkungan hidup juga memasukkan aspek afektif yaitu tingkah laku, nilai dan komitmen yang diperlukan untuk membangun masyarakat yang berkelanjutan yang memahami Manfaat, Fungsi dan pentingnya mengelola limbah rumah tangga dan limbah pertanian. Menurut Azwar, (1986) Pengelolaan sampah bertujuan untuk meningkatkan kesehatan masyarakat dan kualitas lingkungan serta menjadikan sampah sebagai sumberdaya. Dari sudut pandang kesehatan lingkungan, pengelolaan sampah dipandang baik jika sampah tersebut tidak menjadi media berkembang biaknya bibit penyakit serta sampah tersebut tidak menjadi medium perantara menyebarluasnya suatu penyakit. Syarat lainnya yang Ege, dkk, Pembuatan Kompos...67. 
harus dipenuhi, yaitu tidak mencemari udara, air dan tanah, tidak menimbulkan bau (tidak mengganggu nilai estetis), tidak menimbulkan kebakaran dan yang lainnya

Sesuai dengan UU No.23 Tahun 1997 Pasal 5 tentang Pengelolan Lingkungan Hidup, bahwa masyarakat berhak atas Lingkungan hidup yang baik dan sehat. Untuk mendapatkan hak tersebut, pada pasal 6 dinyatakan bahwa masyarakat dan pengusaha berkewajiban untuk berpartisipasi dalam memelihara kelestarian fungsi lingkungan, mencegah dan menaggulangi pencemaran dan kerusakan lingkungan. Sejalan dengan ketentuan tersebut, dalam UU No 18 Tahun 2008 juga menyatakan bahwa setiap orang mempunyai hak dan kewajiban dalam pengelolaan sampah. Dalam hal pengelolaan sampah pasal 12 dinyatakan, setiap orang wajib mengurangi dan menangani sampah dengan cara berwawasan lingkungan.

Meteri kedua, ketiga, keempat dan kelima diawali dengan pemaparan (metode ceramah singkat) dilanjutkan dengan diskusi Tanya Jawab dengan peserta.

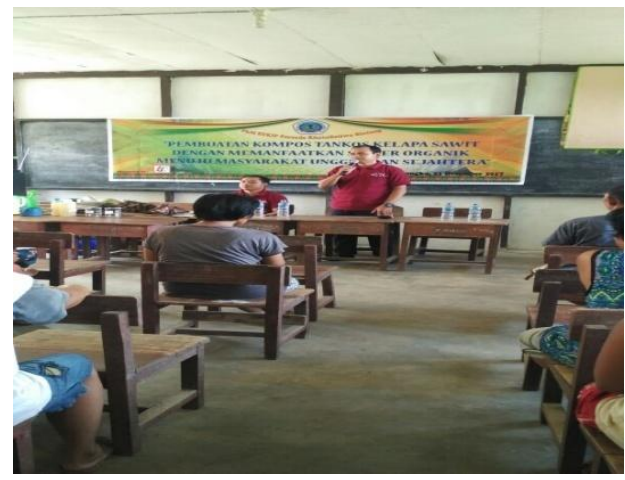

Gambar 1. Pemaparan Tentang Materi

Pada saat diskusi masyarakat sangat antusias untuk bertanya pembuatan kompos tankos kelapa sawit dengan memanfaatkan stater organik, karena selama ini tandan kosong (Tankos) sawit hanya dilihat sebagai sampah yang tidak memiliki arti, dan berserakkan dimanamana, dengan penyampaian materi yang menyampaikan bahwa tandan kosong sawit memiliki manfaat dan bernilai ekonomis masyarakat sangat antusias bagaimana langkah-langkah atau cara agar sampah yang selalu diabaikan dapat berguna bagi mereka.

Setelah pemaparan materi dan diskusi, Tim PkM langsung membawa peserta untuk praktik membuat kompos dari tankos sawit dengan memanfaatkan starter organik. Sebelum membuat kompos yang harus dilakukan adalah membuat starter organik. Bahan yang digunakan yaitu bongol pisang.

Ege, dkk, Pembuatan Kompos...68. 
Kemudian dilanjukan degan simulasi uji coba mol yang dihasilkan dari bongol pisang pada alat yaitu saklar uji coba yang dirancang khusus untuk mengetahui mol apakah bisa digunakan atau tidak. Berikut gambar hasil uji coba:

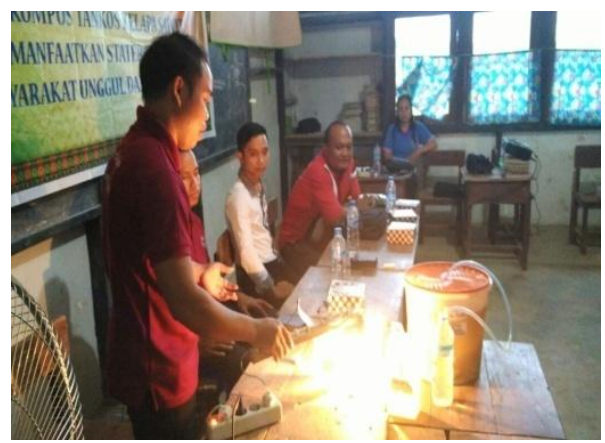

Gambar 2. Uji Coba Mol (Starter Organik)

Berdasarkan gambar diatas tampak bahwa starter dari bahan bongol pisang diujicobakan dengan saklar lampunya menyala, artinya kandungan mol yang dibuat layak dugunakan sebagai stater atau dekomposersasi, dan apabila tidak menyala maka starter tersebut tidak dapat digunakan untuk campuran kompos.

Setelah selesai membuat starter peserta diajak untuk praktik membuat kompos dengan bahan-bahan yaitu tankos sawit, sekam padi(bekatul/dedak), kotoran ayam/kambing. Langkah pembuatannya yaitu tankos sawit dicacah sampai halus dengan parang/pisau, jika sudah halus semua campurkan sekam padi dan kotoran, diaduk sampai rata sambil menyemprotkan mol/starter organik yang telah dibuat. Jika sudah tercampur merata, bahan tersebut dimasukkan kedalam karung kemudian ditutup dengan terpal, apabila sudah 2 minggu karung-karung tersebut dibalik kemudian ditutup lagi. Satu bulan kemudian pupuk tersebut dapat digunakan untuk diaplikasikan pada tanaman hultikultural misalnya cabe, terong, tomat, sawi dll.

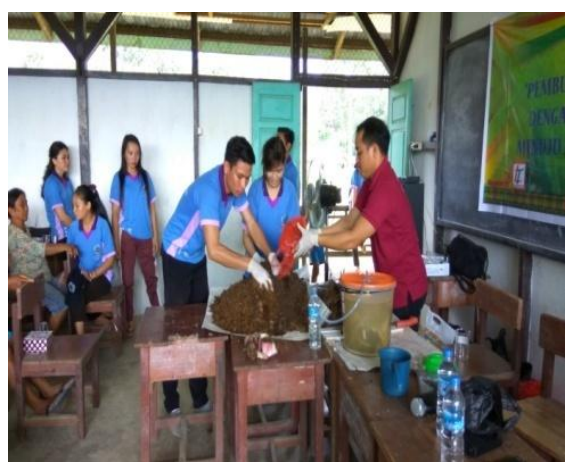

Gambar 3. Praktik Membuat Kompos

Kegiatan berjalan dengan baik dan lancar sesuai dengan yang sudah direncanakan dan dapat dukungan yang baik dari perangkat desa dan masyarakat setempat, akan tetapi kegiatan ini tidak dapat berjalan secara optimal dikarenakan keterbatasan waktu dan anggaran sehingga materi tidak dapat

Ege, dkk, Pembuatan Kompos...69. 
tersampaikan secara optimal kepada peserta.

\section{SIMPULAN}

Kegiatan PkM dalam bentuk Penyuluhan dan Pelatihan yang berjudul "Pembuatan Kompos Tankos Kelapa Sawit Dengan Memanfaatkan Stater Organik Menuju Masyarakat Unggul Dan Sejahtera" sudah berjalan dengan baik dan lancar sesuai dengan rencana kegiatan yang telah disusun meskipun belum semua peserta pendampingan menguasai dengan baik materi yang disampaikan dikarenakan keterbatasan waktu. Kegiatan ini mendapat sambutan dan dukungan yang sangat baik terbukti dengan banyaknya peserta yang mengikuti yaitu ada 52 peserta dan keaktifan peserta mengikuti penyuluhan dan pelatihan/pendampingan dengan aktif, serius dan tidak meninggalkan tempat sebelum waktu pelatihan berakhir

\section{DAFTAR RUJUKAN}

Ayu.N., Aini.N., Herlina. N., 2015. Pengaruh Pemberian Pupuk Organik terhadap Pertumbuhan dan Hasil Tanaman Jagung Manis (Zea Mays Saccharata) pada Tumpangsari dengan Tanaman Kangkung (Ipomea
Reptans). Jurnal Produksi Tanaman. Vol. 1, No, 2, hlm 141-148.

Azwar Azrul. 1986. Pengantar Ilmu kesehatan Lingkungan. Jakarta: Mutiara Sumber Widya

Murbandono. 2000. Manfaat Bahan Organik Bagi Tumbuhan. Pulit Biologi, LIPI, Bogor.

Prihandarini, R. 2004. Manajemen Sampah: Daur Ulang Sampah Menjadi Pupuk Organik. Perpud. Jakarta.

Sintang-Kuala Dua Kembayan. 2016. Online.

http:www.jarakantarkota.com

Suwahyono. S. 2014. Cara Cepat Buat Kompos dari Limbah. Cibubur: Penebar Swadaya.

Tastuti. 2016. Perkebunan di Kalimantan Barat. Online. http:www.triastutiweb.wordp ress.com/2016/10/15/Perkebu nan-di-Kalimantan Barat.

Wikipedia. Pendidikan Pengelolaan Lingkungan Hidup. Online (https://id.wikipedia.org/wiki/P endidikan lingkungan hidup) Diakses Pada Tanggal 24 Januari 2018. 